\title{
Interaction between Guazatine Triacetate and Fructose in Basic Media
}

\author{
Hiroko Kobayashi, Osami Matano and Shinko Goto \\ Chemistry Division, Institute of Environmental Toxicology, \\ Suzuki-cho, Kodaira 187, Japan
}

(Received December 15, 1983)

\begin{abstract}
Constituents in apple and grape which bound guazatine were surveyed, and interactions between the constituents and guazatine were studied. Fructose was a responsible constituent for the binding in basic media, and the active sites of fructose for guazatine were the hydroxyl and carbonyl groups on $\mathrm{C}_{1^{-}}$and $\mathrm{C}_{2}$-position.
\end{abstract}

\section{INTRODUCTION}

Guazatine triacetate, $\left[1,1^{\prime}\right.$-iminodi(octamethylene)diguanidinium triacetate] has been used on various kinds of food crops to control plant pathogenic fungi.

In the preceding papers, ${ }^{1,2)}$ we reported the determination of guazatine triacetate and found that guazatine triacetate was strongly bound on the water soluble constituents in apple and grape, which resulted in the poor recovery of guazatine triacetate added to these fruits. To release the bound guazatine various kinds of reagents were examined, and guanidine hydrochloride was found to be the best reagent. The analytical procedure which was described in the previous paper ${ }^{2)}$ consists of the following three steps: 1) extraction with alkali-methanol containing guanidine hydrochloride, 2) transfer into chloroform and 3) reaction with hexafluoroacetylacetone. It was successfully applied for the residue analysis of field samples.

In the present study, fructose was found to be a strong binding substance for guazatine and interaction between guazatine and fructose under basic conditions was studied.

\section{EXPERIMENTAL}

\section{Chemicals and Reagents}

Guazatine triacetate was offered by Dainippon Ink Ind. Co., Ltd. Hexafluoroacetyl- acetone (HFAA) and guanidine hydrochloride were obtained from Wako Pure Chemical Ind. (Osaka, Japan). Several constituents of apple and grape: Pectine (from apple), L-tartaric acid, D-galactose, D-glucose, L-sorbose and Dfructose were obtained from Tokyo Kasei Ind. D-Fructose-1,6-diphosphate trisodium salt (purity, 98\%), D-fructose-6-phosphate disodium salt (purity, 98\%), D-fructose-6-phosphate barium salt (purity, 87-94\%) and D-fructose1-phosphate barium salt (purity, 98\%) were purchased from Sigma Chem. Co. (USA). All other reagents were of analytical reagent grade.

\section{Gas Liquid Chromatography}

Quantitative determination was performed on a Hewlett-Packard Model 5710-A gas chromatograph equipped with a N-P responsive flame ionization detector (N-P FID). The $30 \mathrm{~cm} \times 2 \mathrm{~mm}$ glass column was packed with $1.95 \% \mathrm{OV}-210$ and $1.5 \% \mathrm{OV}-17$ on $100-120$ mesh Chromosorb W, HP. Helium was used as the carrier gas at a rate of $30 \mathrm{ml} / \mathrm{min}$. The temperatures of column, injection port and detector were 240,250 and $300^{\circ} \mathrm{C}$, respectively. Under these conditions, bis(trifluoromethyl)pyrimidine derivative of guazatine triacetate ${ }^{2)}$ had a retention time of $2.7 \mathrm{~min}$. The sample was quantified by comparison of the peak height with that of an authentic standard. 


\section{Analytical Procedure}

A mixture of each apple constituent $(1 \mathrm{~g})$, $1000 \mu \mathrm{g}$ of guazatine triacetate and $100 \mathrm{ml}$ of $2 \mathrm{~N}$ sodium hydroxide in methanol was shaken with $1 \mathrm{~g}$ of guanidine hydrochloride for 30 min at room temperature. After shaking, 50 $\mathrm{ml}$ of $2 \mathrm{~N}$ sodium hydroxide in methanol and $0.5 \mathrm{~g}$ of guanidine hydrochloride were further added to the mixture and the contents were again shaken for $10 \mathrm{~min}$. The free guazatine was then extracted twice with $150 \mathrm{ml}$ of chloroform after adding $150 \mathrm{ml}$ of distilled water. The organic layer was acidified by adding $2 \mathrm{~N}$ sulfuric acid $(1 \mathrm{ml})$, and evaporated to dryness at $40^{\circ} \mathrm{C}$ in vacuo. The residue was reacted with HFAA as previously described. ${ }^{2)}$ For the control of the corresponding apple constituent, the same procedure was practiced without guanidine hydrochloride.

\section{Post-treatment of Guanidine Hydrochloride}

Each sample (apple constituent, $1 \mathrm{~g}$ ) was dissolved in $5 \mathrm{ml}$ of distilled water. To this solution $1000 \mu \mathrm{g}$ of guazatine triacetate and $100 \mathrm{ml}$ of $2 \mathrm{~N}$ sodium hydroxide in methanol were added, and the mixture was shaken for $30 \mathrm{~min}$ at room temperature. After shaking, $1 \mathrm{~g}$ of guanidine hydrochloride was added and the mixture was again shaken for 15,30 or $60 \mathrm{~min}$ at room temperature, 30,40 or $60^{\circ} \mathrm{C}$. Then $0.5 \mathrm{~g}$ of guanidine hydrochloride and 150 $\mathrm{ml}$ of distilled water were added to the mixture and extracted twice with $150 \mathrm{ml}$ of chloroform. The organic phase was further treated as described in "analytical procedure".

\section{RESULTS AND DISCUSSION}

In the preceding paper, ${ }^{2)}$ we described that guazatine triacetate was strongly bound to the constituents of apple and grape in basic media, and addition of guanidine hydrochloride release guazatine from the bound form.

Table 1 shows the recoveries of guazatine triacetate added to several representative con-

Table 1 Recovery of guazatine triacetate from a reaction mixture of apple constituents and their related compounds with or without guanidine hydrochloride.

\begin{tabular}{|c|c|c|c|}
\hline \multirow{2}{*}{ Compound } & \multirow{2}{*}{$\begin{array}{l}\text { Amount of compound } \\
\qquad(\mathrm{g}(\mathrm{mmol}))\end{array}$} & \multicolumn{2}{|c|}{ Recovery $\left.^{a}\right)(\%)$} \\
\hline & & Without guanidine- $\mathrm{HCl}$ & With guanidine- $\mathrm{HCl}$ \\
\hline Citric acid & $1(4.2)$ & $88.6 \pm 2.4$ & $88.4 \pm 3.5(3)$ \\
\hline L-Tartaric acid & $1(6.7)$ & $86.3 \pm 1.1$ & $87.7 \pm 3.7(3)$ \\
\hline L-Malic acid & $1(7.5)$ & $88.5 \pm 5.0$ & $88.4 \pm 3.4(3)$ \\
\hline Pectine & 1 & $81.5 \pm 9.2$ & $86.8 \pm 2.1(3)$ \\
\hline D-Glucose & $1(5.6)$ & $78.4 \pm 2.8$ & $90.1 \pm 2.8(3)$ \\
\hline D-Fructose & $1(5.6)$ & $\left.30.5 \pm 9.3^{b}\right)(7)$ & $80.7 \pm 9.0(7)$ \\
\hline Sucrose & $1(2.9)$ & $90.5 \pm 4.8$ & $91.3 \pm 3.0(3)$ \\
\hline D-Galactose & $1(5.6)$ & $77.2 \pm 5.3$ & $95.4 \pm 0.8(3)$ \\
\hline L-Sorbose & $1(5.6)$ & $\left.17.8 \pm 3.7^{b}\right)(5)$ & $76.6 \pm 1.6(3)$ \\
\hline $\begin{array}{l}\text { D-Fructose-6-phosphate } \\
\text { disodium salt }\end{array}$ & $1(3.3)$ & $28.8 \pm 2.5^{b)}(3)$ & $83.4 \pm 3.4(3)$ \\
\hline $\begin{array}{l}\text { D-Fructose-6-phosphate } \\
\text { barium salt }\end{array}$ & $1(2.5)$ & $52.1 \pm 5.5^{c)}(4)$ & 100.3 \\
\hline $\begin{array}{l}\text { D-Fructose-1-phosphate } \\
\text { barium salt }\end{array}$ & $1(2.5)$ & $73.5 \pm 4.0$ & 106.5 \\
\hline $\begin{array}{l}\text { D-Fructose-1,6-diphosphate } \\
\text { trisodium salt }\end{array}$ & $1(2.5)$ & $86.2 \pm 1.2$ & \\
\hline Sucrose & $2(5.8)$ & $96.8 \pm 6.1$ & \\
\hline $\begin{array}{l}\text { D-Fructose-1,6-diphosphate } \\
\text { trisodium salt }\end{array}$ & $2(4.9)$ & $71.4 \pm 7.8$ & \\
\hline D-Fructose & $2(11.1)$ & $3.5 \pm 1.5^{\mathrm{b})}(8)$ & $84.4 \pm 5.8(4)$ \\
\hline Control & - & $96.6 \pm 2.9$ & \\
\hline
\end{tabular}

a) Mean \pm S.D., b) and c) Significantly different from values of control, the compounds with guanidine- $\mathrm{HCl}$ and the other compounds at $p<0.001$ and $p<0.01$, respectively. ( ) : No. of samples examined. Amount of guanidine- $\mathrm{HCl}: 1 \mathrm{~g}$. Concentration of guazatine triacetate: $1000 \mu \mathrm{g}(2 \mu \mathrm{mol})$. 
stituents of apple and grape with or without guanidine hydrochloride. The recovery of guazatine triacetate from $1 \mathrm{~g}$ of fructose without guanidine hydrochloride was $30.5 \%$. This value was significantly $(p<0.001)$ lower than those from glucose, sucrose, pectine and organic acids. In contrast, the recovery of guazatine from fructose in the presence of guanidine hydrochloride increased to greater than $80 \%$. These results suggest that fructose is a factor for the binding with guazatine. A similar result was obtained with sorbose. The recovery of guazatine triacetate added to sorbose was $17.8 \%$. The addition of guanidine hydrochloride into sorbose solution especially increased the recovery of guazatine triacetate to $76.6 \%$. On the other hand, the recovery of guazatine triacetate from galactose was $77.2 \%$. This value was the same as that of glucose. The recoveries of guazatine triacetate from glucose and galactose were also increased to $90-95 \%$ by the addition of guanidine hydrochloride. Guazatine triacetate and aldohexose may undergo Maillard type reaction in a manner similar to the reaction of thiourea and glucose. $^{3)}$

Thus, it can be considered that ketohexoses were a more important factor for the binding with guazatine than aldohexoses and interaction between fructose and guazatine triacetate in basic media caused poor recovery of the guazatine triacetate from the apple untreated with guanidine hydrochloride.

In order to clarify the mode of interaction between fructose and guazatine triacetate, the influences of the replacement of the hydrogen at $\mathrm{C}_{1}$ and/or $\mathrm{C}_{6}$ of fructose with the phosphate group on the binding activity were examined. As shown in Table 1, D-fructose-6-phosphate was strongly bound to guazatine triacetate, and the recoveries of guazatine triacetate added to $\mathrm{D}$-fructose-6-phosphate were $28.8 \%$ (sodium salt) or $52.1 \%$ (barium salt). These recoveries of guazatine triacetate from D-fructose-6phosphate sodium salt and D-fructose-6-phosphate barium salt were significantly lower than those from D-fructose-1-phosphate and sucrose. This indicates that the positions of fructose participating in the binding were $C_{1}$ or $C_{2}$ but not $\mathrm{C}_{6}$. The high recovery from $\mathrm{D}$-fructose-6phosphate should be obtained if the hydroxyl group at $\mathrm{C}_{6}$-position of fructose is an active site for the binding with guazatine. Sucrose in which the carbonyl group of fructose moiety is blocked by the glucoside linkage did not influence the recovery of guazatine triacetate. These results apparently indicate that the carbonyl group of fructose plays an important role for the interaction with guazatine molecule.

On the other hand, D-fructose-1,6-diphosphate and D-fructose-1-phosphate had no affect on the recovery of guazatine triacetate, and the recoveries were $86.2 \%$ and $73.5 \%$, respectively. These results indicate that the hydroxyl group at $\mathrm{C}_{1}$-position of fructose was also an active site for the binding. In spite of the presence of the carbonyl group at $\mathrm{C}_{2-}$ position of these compounds, the high recovery of guazatine triacetate may be dependent on the decrease of reactivity of the carbonyl group at $\mathrm{C}_{2}$-position by steric effect of phosphate group at $\mathrm{C}_{1}$-position.

Fructose is the major sugar component of apple and grape. Both fruits usually contain 5-8 $\mathrm{g}$ fructose per $100 \mathrm{~g}$ by weight. ${ }^{4}$ Therefore, recovery of guazatine triacetate was investigated under the presence of $2 \mathrm{~g}$ of fructose. As a result, the recovery without guanidine hydrochloride decreased to $3.5 \%$. This figure approximated to the recovery $(2 \%)$ of guazatine triacetate added to $50 \mathrm{~g}$ of apple. ${ }^{2)}$ Thus, it is concluded that fructose affects the recovery of guazatine triacetate from apple and grape at least under basic media.

For further investigation on the relationship of reactivity among the guazatine triacetate, guanidine hydrochloride and fructose in basic media, a mixture of guazatine triacetate and fructose was shaken with $2 \mathrm{~N}$ sodium hydroxide in methanol for $30 \mathrm{~min}$ at room temperature, and then guanidine hydrochloride was added (post-addition). The mixture was shaken for 15,30 or $60 \mathrm{~min}$ at room temperature, 40 or $60^{\circ} \mathrm{C}$. Under these conditions, the recovery of guazatine triacetate decreased with the rise in the reaction temperature and the increase in the treatment time. When warmed at $40^{\circ} \mathrm{C}$ for 15 to $60 \mathrm{~min}$, the recovery of guazatine triacetate was 0.4 to $0.8 \%$, and at $60^{\circ} \mathrm{C}$, it was less than $0.1 \%$. On the other hand, the recoveries in the control tests were quantita- 
Table 2 Effects of guanidine hydrochloride on interaction between guazatine triacetate and fructose in alkaline media.

\begin{tabular}{|c|c|c|c|c|c|}
\hline \multirow{2}{*}{ Compound } & \multirow{2}{*}{$\frac{\left.\text { Pretreatment }^{a}\right)}{\underbrace{\text { Shaking time }}_{(\mathrm{min})}}$} & \multicolumn{2}{|c|}{ Added guanidine- $\mathrm{HCl}$} & \multirow[b]{2}{*}{$n$} & \multirow{2}{*}{$\begin{array}{c}\text { Recovery } \\
\text { of guazatine } \\
\text { triacetate } \\
(\%)\end{array}$} \\
\hline & & $\begin{array}{l}\text { Shaking temp. } \\
\left({ }^{\circ} \mathrm{C}\right)\end{array}$ & $\begin{array}{l}\text { Shaking time } \\
(\mathrm{min})\end{array}$ & & \\
\hline \multirow[t]{12}{*}{ D-Fructose } & 30 & r.t. & 15 & 3 & $\left.43.9 \pm 1.9^{c}\right)$ \\
\hline & 30 & r.t. & 30 & 7 & $51.3 \pm 8.4^{\mathrm{d})}$ \\
\hline & 30 & r.t. & 60 & 4 & $44.0 \pm 3.1^{\mathrm{c})}$ \\
\hline & 30 & 30 & 15 & 2 & 1.7 \\
\hline & 30 & 30 & 30 & 2 & 4.0 \\
\hline & 30 & 30 & 60 & 2 & 3.3 \\
\hline & 30 & 40 & 15 & 2 & 0.8 \\
\hline & 30 & 40 & 30 & 2 & 0.4 \\
\hline & 30 & 40 & 60 & 2 & 0.4 \\
\hline & 30 & 60 & 15 & 2 & 0.1 \\
\hline & 30 & 60 & 30 & 2 & ND \\
\hline & 30 & 60 & 60 & 2 & $\mathrm{ND}$ \\
\hline D-Glucose & 30 & r.t. & 30 & 2 & 82.4 \\
\hline \multirow[t]{2}{*}{ D-Fructose } & 30 & - & 一 & 7 & $30.5 \pm 9.3$ \\
\hline & 一 & r.t. & 30 & 7 & $80.7 \pm 9.0$ \\
\hline Control & $60^{\mathrm{b})}$ & - & - & 3 & $88.9 \pm 4.6$ \\
\hline
\end{tabular}

a) Shaking temp.: r.t., b) Shaking temp.: $60^{\circ} \mathrm{C}$, c) Significantly different from values of the compound with guanidine- $\mathrm{HCl}(p<0.001)$ and without guanidine- $\mathrm{HCl}(p<0.01)$, d) Significantly different from values of the compound with and without guanidine- $\mathrm{HCl}(p<0.001)$.

ND: Not determined. Concentration of guazatine triacetate: $1000 \mu \mathrm{g}$. Amount of guanidine$\mathrm{HCl}: 1 \mathrm{~g}$.

tive even at a heating temperature of $60^{\circ} \mathrm{C}$. Under these conditions, guazatine triacetate is stable. Actually, the compound is hydrolyzed to octamethylenetriamine when reacted for $30 \mathrm{~min}$ at $130^{\circ} \mathrm{C}$ under the pressure of $2 \mathrm{~kg}$ / $\mathrm{cm}^{2}$ in alkaline media. ${ }^{5)}$

In addition, the results in Table 2 indicate that the value of recovery $(80.7 \%)$ of guazatine triacetate from fructose by pre-addition of guanidine hydrochloride was significantly $(p<$ $0.001)$ higher than that $(51.3 \%)$ of post-addition of guanidine hydrochloride. From the result in the post-addition of guanidine hydrochloride, it is apparent that a part of guazatine triacetate was bound with fructose and was no longer released by addition of guanidine hydrochloride. Thus, the pre-addition of guanidine hydrochloride makes it possible to avoid the binding of guazatine triacetate with fructose in alkaline media but the guazatine triacetate was not quantitatively recovered by post-addition of guanidine hydrochloride.

Interaction between guazatine triacetate and fructose is less readily explained. However, the results described above suggest that the reaction of the guazatine and fructose may proceed by the mechanism similar to Maillard reaction or the cyclization reaction of guanidino compounds with benzoin to form imidazole derivatives. ${ }^{6)}$

\section{REFERENCES}

1) H. Kobayashi, O. Matano \& S. Goto: J. Pesticide Sci. 2, 427 (1977)

2) H. Kobayashi, O. Matano \& S. Goto: J. Pesticide Sci. 7, 513 (1982)

3) G. Westphal \& L. Kroh: Nahrung 25, 311 (1981)

4) R. E. Wrolstad \& R. S. Shallenberger: J. Assoc. Off. Anal. Chem. 64, 91 (1981)

5) Dainippon Ink Ind. Co., Ltd.: personal communication (1975)

6) Y. Ohkura \& M. Kai: Anal. Chem. Acta 106, 89 (1979) 


\section{要約}

酢酸グアザチンとフルクトースのアルカリ溶液 中での反応

小林裕子，俣野修身，後藤真康 酶酸グアザチン guazatine triacetate $\left[1,1^{\prime}\right.$-iminodi(octamethylene)diguanidinium triacetate] はアルカリ 溶液中において，りえごおよびぶどう中の成分に結合し
やすい，そこで，りんごおよびぶどう中のどの成分に結 合するかを検討した，その結果，フルクトースがグアザ チンに結合する要因物質の一つであることが判明した。 また，フルクトースのぞの位置がグアザチンとの反応に 関与しているかを検討した結果， $\mathrm{C}_{1}$ 位打よび $\mathrm{C}_{2}$ 位にお ける水酸基打よびカルボニル基が関与していると推定で きた。 